\title{
Moral economy: Rethinking a radical concept
}

Jaime Palomera ${ }^{1}$

Universitat de Barcelona, Spain

Theodora Vetta

Universitat de Barcelona, Spain

\section{Abstract}

This article argues that the original thrust of the moral economy concept has been understated and attempts to cast it in a new light by bringing class and capital back into the equation. First, it reviews the seminal works of Thompson and Scott, tracing the origins of the term. It deals with the common conflation of moral economy with Polanyi's notion of embeddedness, differentiating the two concepts and scrutinizing the ways in which these perspectives have been criticized. Second, it dispels dichotomist conceptions separating economic practice from morality, or embedded configurations from disembedded ones. Against binary views of the market as a boundless realm penetrating previously untainted moral spheres, it posits that social reproduction is characterized by an entanglement of values, which can only be fully grasped by delineating the contours and characteristics of capital accumulation. Third, it contends that moral economy is a dynamic concept because it accounts for class-informed frameworks involving traditions, valuations and expectations.

1 Corresponding authors:

Jaime Palomera and Theodora Vetta, Department of Anthropology, Universitat de Barcelona, Carrer de Montalegre 6, 08001 Barcelona, Spain. 
Finally, it argues that moral economy can enrich the concept of hegemony because it pays attention to the often-contradictory values that guide and sustain livelihood practices, through which cultural domination is reproduced or altered.

\section{Keywords}

capital, class, embeddedness, hegemony, moral economy, Polanyi, Scott, Thompson

\section{Introduction ${ }^{1}$}

In the last two decades the moral economy concept has reemerged with strength. However, as often occurs with catchy categories, scholars have approached it in contradictory ways. Among its different uses, two main strands stand out. On the one hand, moral economy has been used to scrutinize systems of provisioning that seem to emerge 'outside' or 'in the cracks of' the market. 'Solidarity', 'alternative' or 'informal' practices usually constitute the target. In these analyses, moral econ- omy is synonymous with an organized field of values, where economic practice appears 'embedded' in moral obligations and social norms (Olivier de Sardan, 1999; Tripp, 2006; Orlando, 2010; Langegger, 2015). As Hann has noted in a recent reappraisal (2010), the central characteristic of this approach is that by highlighting values and norms, it challenges economistic views. On the other hand, the growing interest in systems of values and norms per se has increasingly led scholars to drop the production and distribution of resources from the picture. In his 2009 article 'Les économies morales revisitées', Fassin critically discussed some of these instances, saluting their conceptual departure from Thompson's original rumination (1971) and warning about 
the risk of culturalization and depoliticization. Fassin's own work is paradigmatic of this second trend, where semantic weight has shifted from the noun (economy) to the adjective (moral). As he admits, his interest lies less with moral economies than with the economy of morals, that is, 'the production, distribution, circulation and use of moral feelings, emotions and values, norms and obligations in the social space' (Fassin, 2009: 1257, our own translation). In other words, the economy in capital letters has ceased to be the object of analysis, leaving the spotlight on the study of morals (Daston, 1995; Fassin, 2009). As a result, moral economy has quickly become a strange guest in the bourgeoning field of 'moral anthropology' (Zigon, 2007; Fassin, 2012).

Though both kinds of literature offer tremendously relevant insights, the problem is that the original thrust of the concept has been understated, to the point of obscuring social relations rather than explaining them. As advised by Thompson (1991) and recalled by Edelman $(2005,2012)$, if simply equated with 'values' and emptied of class content, moral economy loses its raison d'être: anything can be deemed a moral economy. In this article we want to reclaim the radical foundations of the term by bringing capital and class back into the equation. This 'return to the roots' will hopefully not be read as an empty programmatic slogan, but as a theoretical operation that casts light on moral economy both as a concept and an approach.

First, conceptually speaking, we build on some of the insights that Narotzky developed in a recent article (2015). We contend that the structural inequalities generated by particular forms of capital accumulation - mediated by particular kinds of state regulation - are always metabolized through particular fields constituted by dynamic combinations of norms, meanings and practices. It is these fields that we call moral economies. They can 
reproduce or strengthen patterns of capital accumulation that regulate social structure, but they can also alter and even shortcircuit them. As will be gleaned from our analysis below, the original moral economists point at nothing other than a historical shift from a particular moral economy of capitalism to a new moral economy. Following this line of thought, our article runs counter to a sort of common sense that restricts the concept to a particular social actor probably deriving from the fact that Thompson himself originally talked about the moral economy 'of the English crowd'. We instead argue that analytical mileage can be gained by using it in relation to broad social fields of thought and action, which involve difference and antagonism, and contribute decisively to shaping the field of provisioning and social reproduction. Thus, we can for instance speak of the moral economy of European integration (Gkintidis, this issue), or the moral economy of flexible production (Kofti, this issue) and the different values, meanings and practices that arise around them, attached to differently positioned actors, and always linked to disparate class experiences.

Second, we assert that moral economy is simultaneously an approach that inte- grates the traditional objects of political economy (relations between capital, class and state) but goes further by anthropologically scrutinizing the particular ways in which they are always embedded. In other words, the moral economic approach has a double 'mission': on the one hand, it advocates a grounded understanding of the more abstract and global politicaleconomy processes; on the other, it histori- cizes the everyday realm of observation by accounting for class-informed dispos- itions in a particular time and space. Moral economy is particularly well suited to analyze the political culture, norms and expectations of the various groups of people involved in social reproduction, 
broadly speaking; the power relations between the governed and the elites; and the articulation of such dispositions and relations with capitalist processes of continuity and change. The strength of this perspective lies in its capacity to highlight the ambiguous logics and values that guide and sustain livelihood practices, by looking at the dynamic fields of struggle around the boundaries of what is good and acceptable, their power hierarchies and the political projects they might inform.

The article is structured in four parts. First, it reviews the seminal works of Thompson and Scott, tracing the origins of the concept. It deals with the common conflation of moral economy with Polanyi's notion of embeddedness, and the ways in which this perspective has been criticized. Second, it dispels dichotomist conceptions separating economic practice from morality, or embedded configurations from disembedded ones. Against binary views of the market as a boundless realm penetrating previously untainted moral spheres, it posits that social reproduction is characterized by an entanglement of values, which can only be fully grasped by delineating the contours and characteristics of capital accumulation. Third, it contends that moral economy is a dynamic concept because it accounts for class- informed frameworks involving traditions, valuations and expectations. This, in fact, is the key element that differentiates it from the embeddedness thesis. Finally, it argues that moral economy can enrich the notion of hegemony because it pays attention to the often-contradictory values that guide and sustain livelihood prac- tices, through which cultural domination is reproduced and altered.

\section{The origins of moral economy and its discontents}

The concept of moral economy was popularized by the seminal work of E.P. Thompson. In his 1971 essay 'The Moral Economy of 
the English Crowd', the historian focuses on the food riots in 18thcentury England, in an attempt to reveal the historical agency of 'the crowd' and to argue against 'spasmodic views of popular history' that naturalize and reduce people's actions to automatic quasibiological responses to hunger. The brilliance of his work consists not only in that it unpacks the complex motivations and choices behind this particular pattern of collective action, but also in that it takes them as a window onto a wider socio-economic process: namely, the long transition from a system of provision framed by paternalist institutions to an emerging political economy regulated by so-called free market policies, which benefited particular sectors of the bourgeoisie. These changes were well under way from the mid1700 s on, accompanying the gradual repeal of protective legislation. Yet as Thompson describes, in times of dearth, a particular consensus emerged between, on the one hand, town laborers and crafts- men and, on the other hand, local magistrates and the gentry. This was based on a widely shared mentalite' about emergency market-regulation in favor of the unprivileged and the poor. When different groups (tinners, carpenters, weavers and col- liers) chose to attack a series of social targets (mills, farmers withholding corn and suspicious middlemen) they did it with the purpose of, first, punishing immoral profit-seekers (rather than stealing to satisfy their hunger) and second, fixing prices.

Their actions, as Thompson stresses, were informed by a popular consensus as to what were legitimate and what were illegitimate practices in marketing, milling, baking, etc. This in its turn was grounded upon a consistent traditional view of social norms and obligations, of the proper economic functions of several parties within the community, which, taken together, can be said to constitute the moral economy of the poor. An outrage to these moral assumptions, quite as much as actual deprivation, was the usual 
occasion for direct action. (1971: 79)

As he concludes, the point here is not just that prices, in time of scarcity, were determined by many other factors than mere marketforces: anyone with even a scanty knowledge of much- maligned 'literary' sources must be aware of that. It is more important to note the total socioeconomic context within which the market operated, and the logic of crowd pressure. (1971: 125)

The other key author who contributed to popularizing the moral economy concept is James Scott. Although he barely refers to Thompson in his original work (beyond fleeting references), the notion is deployed to analyze peasant households in 20th-century Burma and Vietnam (1976). Starting from the micro setting of everyday life, he also reveals their livelihoods' entanglement with larger transformations, namely colonial state formation and free-market expansion. Crucially, the focus is not so much on the acts and exact causes of peasant rebellion (which Moore or Wolf had tackled in 1966 and 1969, respectively) than on their very conditions of possibility. It is about the nature of exploitation in peasant society as its victims are likely to see it, and what one might call the creation of social dynamite rather than its detonation' (1976: 4). Scott speaks of 'the moral economy of the subsistence ethic'. Against the maximizing homo oeconomicus of neoclassical economics - or 'the would-be Schumpeterian entrepreneur' (1976: 4) - peasants are framed as risk-averse social agents, having as their guiding value a 'safety-first principle'. This very quest to guarantee a minimum level of subsistence informs their 'notion of economic justice and their working definition of exploitation - their view of which claims on their product were tolerable and which intolerable' (1976: 3). Thus, Scott sees peasant mobilizations not as a direct outcome of absolute surplus extraction, but as a violation (backed by the colonial state) of a social pattern of moral 
entitlements and expectations that used to define unequal yet tolerated power relations both among peasants within the village and with outside elites and patrons (1976: 6).

With their contributions, Thompson and Scott laid the groundwork for a potentially very rich field of analysis. Moral economy seemed particularly well suited to illuminate broad processes of continuity and change by looking at the ways in which laboring people understand and become involved in actions in the market (their political culture, dispositions, traditions, etc.) and their changing social alli- ances with economic elites and the state. In other words, the original moral economists put forth the theoretical foundations for thinking about social reproduction at large, while keeping a grounded perspective - particularly in contexts where market forces and the logics of capital accumulation are becoming dominant.

However, much of the recent literature engaging with the notion of moral economy and actually dealing with economic practice has generally not followed along in the footsteps of its founders. First, there is a common tendency to constrain the notion of moral economy to particular groups, which blurs the conflictual fields of thought and action they are part of. Such a problem possibly comes from the fact that Thompson and Scott themselves spoke, misleadingly, of 'the moral economy of the crowd' and 'the moral economy of the peasant'. Yet, as Kofti suggests in this issue, moral economy can only be associated with an actor if it also designates, complementarily, the broad field in which such an agent is inscribed. And even then, locating a particular subject for a moral economy involves challenges that are very hard to rise to, such as 'the identification of a social group with a common moral economy', or the analysis of 'people's individual ideas and practices and their relation to collective moral frameworks' (Kofti, this issue).

Second - and partly as a result of circumscribing the concept to 
actors and their micro-spheres - the expansion of capitalist markets and their extremely complex social underpinnings tend to stay outside of moral economists' research interests. Moral econom(ies) are more-often-than-not portrayed as particular realms outside (or in the cracks of) the market and the state, as reciprocity-systems of survival linked to particular groups, often unprivileged ones. Thus, the term becomes associated with the ways in which different actors 're-embed' their relations in more equal and altruistic modes of social reproduction, such as religious projects of restoration (Tripp, 2006), alternative practices around fair-trade (Orlando, 2010; Psarikidou and Szerszynski, 2012) or unconventional ways of exercising rights to property (Langegger, 2015). As one can infer, these dominant approaches treat moral economy as an approximate synonym of Polanyian embeddedness (Hann, 2010): a heuristic tool to study the ways in which small-scale economies are more or less embedded in complex arrays of norms, values and institutions. Some authors have also deployed the term to reflect on alternative political projects that might foster higher degrees of solidarity and 'embedded sociality' (Sayer, 2000; Bolton and Laaser, 2013).

In their effort to challenge vulgar economism, moral economists have ended up avoiding the market and - more specifically - the pervasive logics of capital as much as embeddedness theorists (Krippner, 2001). In this sense, a key feature of this particular approach to the moral economy concept is the portrayal of norms and values (sustained by specific communities) as inherently positive or good vis-à-vis the fragmenting and individualistic nature of a market without norms. Such an understanding derives from a mainstream reading of E.P. Thompson's 1971 essay, pointing to an analytical and historical distinction: a 'moral economy' period preceding - and in opposition to - the 'political economy' of 19thcentury England; the story of a world defined by moral obligations 
and dependences being eroded and replaced by contractual market relations. Of course this analysis has long been disputed. The most popular critique is that this schema constitutes a highly dichotomous and evolutionary view of history: it allegedly romanticizes past social arrangements vis-à-vis amoral or 'less moral' capitalist formations (Fox-Genovese, 1973; Popkin, 1979; Booth, 1994; Götz, 2015).

Interestingly, Karl Polanyi's texts have also been criticized for allegedly partak- ing in such a binary reading of history. Polanyi is often thrown into the mix because Thompson's and Scott's arguments partly overlap with that of The Great Transformation. Though the latter never engaged with the former in their original work, Polanyi has been sometimes somehow approached as a moral economist avant la lettre. Hann has even called him 'the most sophisticated theoretician of the moral economy writ large' (2010: 196). As is well-known, in his major work, the Hungarian author analyzed the implementation of laissez-faire doctrines in the 19th century, contending that they had had a profoundly negative impact on different social institutions, mores and customs. In standard readings, Polanyi is often quoted for having stated that, with the rise of market society, 'instead of economy being embedded in social relations, social relations are embedded in the economic system' (2001: 77). The common deduction is that Polanyi treats the market itself as 'disembedded'.

The inclusion of Polanyi - and of his purportedly dichotomist approach - in the critique of moral economy is best exemplified by William James Booth. In his 1994 article, he specifically talks about the theoretical center of the moral economic approach being the defining opposition of the embedded economy versus the disembedded, or autonomous, market. For Booth, the embedded/disembedded conceptual framework tends to 
misconstrue the normative character of modernity: '[it] obscures the character of market society by simultaneously understating the presence of recognizable and distinct economic behavior in archaic societies and insisting on too radical a detachment of the modern economy from its sustaining institutional and normative nexus' (1994: 662). He argues that even if moral economists warned against idealizing 'pre-modern communities', they could not avoid doing so: they presented them as realms of solidarity and equality where individual profit-making and hierarchies were neutralized in the name of the common good. According to this view, they built this ideal model and then used it as a mirror to present modern societies as commodified and dominated by the self- regulating mechanisms of the market. Against it, he argues that any economy is suffused with the norms of the community of which it is a part, and that economic relations and values of communities are generally in a relation of reflective equilibrium.

\section{All economies are moral economies}

Most contemporary appropriations of the moral economic approach have certainly tended to institute this binary thinking, reducing the sphere of the normative to economies that are generally peripheral or articulated with an inherently amoral market. In this sense, Booth (1994) made an important statement in moral economy theory, one that is necessary to recuperate and emphasize: all economies, including the market societies of late-capitalism, are moral economies. However, we argue that in order to do so he partially misconstrued the texts of his predecessors, somehow reducing them to straw men.

To begin with, the rich descriptions provided by Thompson and Scott of the English crowd or Burmese peasants are all but a romantic account of some com- munity-bound world. In different 
passages of their work, both authors stress the unequal character of protectionist social arrangements and interventions. Thompson, for instance, shows that even when the gentry decided to actually appeal to the old paternalist laws, law enforcement was selective and fragmentary and 'directed almost without exception against petty culprits, local wide-boys or market-men, who pocketed small profits on trivial transactions - while the large dealers and millers were unaffected' (1971: 64). Scott, responding to the criticism of romanticization, has more recently emphasized that 'such forms of social insurance had never been practiced as a matter of altruism or noblesse oblige either by local elites or the state. Instead, they were a response to the immanent threat of theft, arson, riot, or rebellion by a hard-pressed peasantry defending its right to survive' (2005: 397). In fact, he had already warned about this in his original piece: 'it is all too easy, and a serious mistake, to romanticize these social arrangements that distinguish much of peasant society. They are not radically egalitarian. Rather, they imply only that living is attained often at the cost of a loss of status and autonomy' (1976: $5)$. In his account, therefore, social consensus was not based on disinterested intentions or social justice. Forms of inequality were not absent, but they were largely tolerated.

More importantly, only if taken at face value can the texts of the first moral economists be defined as dichotomist. In the 1991 revisit to his original article, Thompson clarifies that the new capitalist world of the 19th century was not an amoral one. Thompson is well aware that Adam Smith, who authored The Wealth of Nations - a 'superb, self-validating essay in logic' (1971: 91) - is also the thinker behind The Theory of Moral Sentiments: a treaty 'grounded in the liberal moral philosophy of the 18th century enlightenment' (1991: 271). Although he does not state it explicitly, Thompson is talking about the shift from a particular moral economy to a new moral 
economy (a possibly clearer framework than his confusing distinction between 'moral economy' and 'political economy'). This shift is characterized by the development of a series of laissez-faire policies that attempted to disinfest the market of the kind of moral imperatives that had hitherto preserved the interests of a social majority (1991: 89-90): 'the market economy created new moral problems [.. .] This was not so much to separate morality and economics, as to adopt a particular type of morality in the interests of a particular type of econ- omy' (1991: 271, quoting Atiyah). And, one might add, in the interests of certain social classes. Thompson leaves no doubt: the mere idea of evacuating the market of moral imperatives was a superstition of those social groups and their ideologues. Yet this does not contradict the fact that, by destroying a whole range of protectionist measures and promoting the commodification of social life on a different scale, 18th-century capitalism inaugurated a radically different moral economy.

A similar reading is applicable to Polanyi's work, which also functions on these two levels. Polanyi argues that, with the advent of industrial economies in the 19th century, capital markets came to dominate all spheres of social organization. Indeed, he shows how the proponents of the 'liberal creed' (Malthus, Ricardo, Smith and their subsequent followers) envisioned a world in which the economy would be disembedded from social institutions and norms. In fact, they actively worked for this, advocating government policies that deprived the peasantry of the means and institutions for selfprovision (Perelman, 2000). However, Polanyi clearly underlines that a disembedded market economy, completely self-regulated, is impossible: 'Our thesis is that the idea of a self-regulating market implied an absolute utopia' (2000: 18). The expansion of unfettered markets and their destructive effects on social institutions generate a 'double movement': the more autonomy markets are given and the 
stronger the pressures for commodification (of people, land and money) are, the bigger the urge for protectionist forms becomes. In fact, like Thompson, Polanyi shows in his historical examples the ways in which differ- ent class fractions (crown, segments of the aristocracy, artisans, peasants, and workers) were occasionally able to impede or at least restrict the play of market forces by invoking particular moral norms and arrangements and pushing the state to intervene in different ways. Market society, as he calls it, is a political construction, shaped by 'continuous, centrally organized and controlled interventionism' through the state. So-called market self-regulation is only possible (and to a very limited extent) provided that the state is aggressively and deeply involved in it. And even then, economic relations are always embedded in institutions of different kinds - such as religious or domestic - that are as important as the central banks that issue currencies or the machines that increase productivity at the work- place (Block, 2001; Krippner, 2001; Hann and Hart, 2011).

The legacy of the original moral economists, moreover, prompts us to avoid treating the market as a boundless amoral force that ultimately commodifies (and destroys) so-called 'moral economies' (characterized by norms and non-instrumental values). It urges us to see that market processes cannot be set in opposition to extraeconomic cultural and social forces. By the same token, it is important to bear in mind that stressing the 'cultural' or 'moral' aspects of market transactions does not imply disregarding the underlying logics of market transactions them- selves -a tendency that has produced views of the market that are as 'disembedded' as those of orthodox economists (Krippner, 2001; Krippner et al., 2004). Briefly put, economic phenomena under capitalism might display features (such as the laws of supply and demand) that make them partly autonomous, but they are at the same time always 
interdependent with systems of meanings, institutions, and structures of social relations (Zelizer, 1988: 619).

Insights on the problem of 'value regimes' (Appadurai, 1988) have allowed anthropologists to scrutinize these interdependences. The literature on the complex nature of gifts and commodities shows that the rise of a standard measure of value - represented by market relations - cannot do away with the constant proliferation of other forms of value that are simply incommensurable. The question of why some objects cannot be counted and are considered inalienable while others change value as they move across different regimes underscores a broader debate about the fuzzy boundaries between morality and market exchange (Gregory, 1982; Munn, 1992; Weiner, 1992; Strathern, 1988; Graeber, 2001). In a similar vein, Valerio Simoni's study of Cuban immigrants in crisis-ridden Spain (this issue) seeks to understand what counts for economic and what counts for moral for his inform- ants. In order to do so, he brings into the discussion current debates in moral anthropology (Robbins, 2007; Zigon, 2007, 2014) as well as performativity approaches to economization (Callon, 2007; C, alis, kan and Callon, 2009). Simoni deliberately uses the moral economy concept in a flexible way since this gives him the possibility to conceptually navigate between structural and ontological analyses. Embeddedness and economization, he contends, counterbalance each other. It is in their interplay that we can find a productive field of possibilities for theoretical elaboration. Whereas he acknowledges the usefulness of the Thompsonian moral economy concept in highlighting emic notions of social just- ice, entitlements and moral obligations, Simoni also rightly urges us to be cautious in adopting abstract analytical categories such as the economy or the social, par- ticularly when the ethnographic subjects produce contentious frames to differentiate spheres or sets of values. For example, among several of his 
informants, 'rather than the economy, what was invested morally was the divide between the "economic" and the "social, between sentiment and interest and calculation a divide between two radically different spheres of value and modes of being, cast here as incompatible'.

We completely share Simoni's view that if we are to understand the livelihoods of our interlocutors, the least we need to do is to listen to their 'competing articulations of moral economic reasoning'. Indeed, we might add that embeddedness and economization approaches are not as contradictory as they initially seem, for yet a further reason. Embeddedness points to the fact that discourses and valuations always emerge as intertwined with and inseparable from actual practices of production, exchange and reproduction. Thus, Simoni's fascinating paper begs the question of why certain interlocutors insist on treating economy and morality as autonomous fields in spite of their seeming entanglement, and whether this responds, for instance, to emotions and interests that change dependent upon their material conjuncture (shifts regarding the content of their actual relations, their socio-economic trajectory, etc.). In our view, 'de-moralizing' views of the economy are more often than not a way of moralizing the economy differently, without presupposing the actual existence of the latter as a separate realm.

\section{Bringing capital accumulation back in}

Acknowledging that all economies are moral economies is crucial to our under- standing of the market. But it is not enough. In order to grasp the different dimensions and qualities of embeddedness it is crucial to bring capital into the heart of the analysis. In other words, asking 'what kind of embeddedness' implies simultaneously asking 'what kind of patterns of accumulation'. Paradoxically, analysis of the macro and micro dynamics of capital, and of the way in which 
they inter- twine with norms, social institutions and the state, remains marginal (if not inexistent), even in rigorous analyses that directly target reproduction 'logics' in order to deconstruct essentializing cultural explanations (see Olivier de Sardan, 1999). A notable exception can be found in the recent study of the 'moral economy of violence' in the US, led by Karandinos et al. (2014). In their rich portrayal of everyday life in the streets of North Philadelphia, this team of ethnographers shows how moral configurations of gift-giving and mutual violence are embedded in the class relations that make up the drug market. By returning to a thick usage of embeddedness, they show how the casual relations of their street-corner informants are simultaneously traversed by the macro logics of capital and the state. The problem with this study, however, is that its theoretical framework seems unable to fully break away from the dichotomist perspective, as it builds on the preconception of two distinct realms: that of the 'Maussian gift economy' and that of 'primitive accumulation'.

Dimitra Kofti's analysis of glass-factory workers in Sofia (in this issue) makes an important step towards bridging these domains. Kofti frames her analysis as the moral economy of flexible production'. She builds a multi-dimensional and multi- scalar understanding of moral economy, using it as an encompassing approach to phenomena involving various social groups and collective frames, but also individual ideas and strategies. As she argues, understanding current inequalities under the regime of flexible capitalism necessarily means bringing together moral valuations at the household and at the production line. Like Scott, she asks: 'what do people find acceptable and unacceptable, and what might lead them to take action or what might mute an action?' For the precarious women working at the cold end, certain kin obligations, status and gender shifts in the household are morally 
prioritized over collegial solidarity on the shop floor. While labor inequalities are explicitly acknowledged, conjugal family strategies or gender empowerment linked to labor hinder collective action by augmenting the fear of layoff. Kofti frames her analysis as 'the moral economy of flexible production', based on the entanglement of two separate economic spheres: the household and the factory. This approach builds a multi-dimensional and multi-scalar understanding of the concept. Kofti demonstrates that the intertwining of different values needs to be taken into account if we are to understand the current accumulation regime both in terms of continuity and potential change.

The moral economy approach that we propose here incorporates and tries to go beyond the debates on market and morality by recognizing that capital accumulation is structurally inscribed in the everyday dynamics of social reproduction. Like Zelizer (1988), we distance ourselves both from the economic absolutism of the neoclassical school, but also from culturalist and structurally reductionist models of the market. In fact, ethnographic cases of social reproduction in late capitalism tend to show that the increase of marketization and commodification does not necessarily imply a decrease in relations marked by affect and moral obligations. The form that social labor takes, for example, in small family firms and farms entering an international division of labor as subcontractors in highly competitive markets is an exemplary case of value enmeshment (Blim, 1990; Ghezzi, 2003; Narotzky, 2015).

Here, the question is not to evaluate the ways in which abstract market principles and logics are articulated with non-market relations. The micro settings that constitute the standard space of observation for anthropologists are always permeated with ambiguous logics, where self-interest, competition, market commensurability and commodification overlap with dependency, norms 
and incom- mensurable values (Gregory, 1997; Guyer, 2004; Gudeman, 2008). Value regimes are intertwined, quite indiscernibly. In spite of a recurring temptation to frame them according to binary oppositions, empirical observation reveals that they can be better understood through the topology of the Moebius strip (Sabel, 1991): as apparently distinguishable realms that in fact co-exist on the same plateau, in continuity. It is this very entanglement that sustains certain patterns of capital accumulation (Narotzky and Besnier, 2014; Palomera, 2014; Narotzky, 2015). As Susana Narotzky has argued, flexible capitalism is based not only on the opportunistic use of existing reciprocal relations and moral obligations for the purpose of capital accumulation but on their transformation into a new kind of ambivalent reality [.. .] This overlapping of the realms of value enables a particular form of exploitation by capitalist firms and a particular mode of governmentality that continuously shifts and blurs conflict locations and obscures knowledge about the localized and globalized processes of capital accumulation. (2015: 185, 191)

The moral economy approach explores and explains these ambiguities, taking into account the spatio-temporal conjuncture and the conditions of possibility that actors encounter in their pursuit of livelihood.

\section{Capital and class, reproduction and change}

Looking at how values, practices and relations are linked to patterns of accumulation defies the notion of moral economies as stable frameworks where cultural/ moral values and norms are static. In light of this, it is rather surprising that the main criticism lodged against the original moral economists is their alleged inability to account for social change (Popkin, 1979; Booth, 1994; Wegren, 2005). The works of Thompson, Scott and Polanyi have been 
challenged, first, because their analyses purportedly view social actors as change-resistant subjects, looking to maintain past arrangements; and, second, because moral economy is supposedly built in terms of social consensus and equilibrium. 'The moral economic approach', as Booth argues, 'is, in other words, oriented toward the static state and is therefore less valuable when the question is of change across time' (1994: 658). In order to back these arguments, repertoires of individual decision-making are emphasized. Popkin for instance is known for having famously coined the ideal-type of the 'rational peasant' (1980) in order to underline the 'investment logic' and the self- interested calculative choices of peasants. In his view, the decisions of the latter are motivated not solely by concerns about protection but also by incentives for personal gain and future betterment, thus fostering the unequal stratification of their communities.

Far from these arguments, we contend that moral economy was originally conceived as a dynamic concept, capable of accounting for class-informed frameworks of meanings and expectations. The moral economic approach deals with the complex fields of struggle in which livelihood projects are involved, always tied to a particular moment and social structure. The 'consensus' that Thompson refers to does not imply that moral economy is reduced to coercion or habit and customs. On the contrary, he sees the market and social reproduction as spaces where class relations are constantly renegotiated. Consensus or continuity are not about voluntary agreement or free will, but most often an outcome of social struggle, which has its winners and losers. As Orlove puts it, moral economy tries to 'incorporate culture into analyses of class and political action', showing that 'people struggle not only for wealth and for power, but also for dignity' (1997: 260). Beyond the absolute priority that Adam Smith gives to 'property rights' and 'profit rights', 
Thompson pays attention to the web of 'entitlements' and 'responsibilities' which constitute the social and political basis of the economy or the market. He underlines that 'conflict over entitlement to food in the market might be seen as a forum of class struggle, if most of historians were not too prissy nowadays to use the term' (1991: 287). 'Food prices were not merely one point of conflict between working and property-owning classes over the material control of an economy, but were linked to class-specific notions of social rights and responsibilities' (1991: 259). There is little basis therefore for arguing that the riots described by Thompson were nostalgic movements to restore 'traditional systems'. Rather, we agree with Edelman that they were future-oriented (2005), as they partook in the historical strife among hierarchically-positioned social groups to define entitlements and rights, forms of social responsibility and obligation, tolerable levels of exploitation and inequality, meanings of dignity and justice. For Thompson, the 'market economy' is nothing else than a metaphor (or mask) for capitalist process, worn by particular interests. The 'market' is 'a mystifying metaphor for the energies released and the new needs (and choices) opened up by capitalist forms of exchanges, with all conflicts and contradictions withdrawn from view' (1991: 305).

Therefore, moral economy is dynamic by definition, and reproduction or change depends on the particular interface among shifts in capital accumulation patterns, mentalities (or borrowing Bourdieu's term, dispositions) and relations between class fractions. Thompson describes an old redistributive paternalist arrangement that did not simply depend on the altruism of the elites: it was 'a calculative stance in the culturally constructed alliance between patricians and the plebs against the middling orders, and it distracted attention from the landowners' prosperity to point to prominent Dissenters and Quakers among the profiteering food 
dealers' (1991: 301). The state, with its multi-layered agents, played a protagonist role as well in these struggles and alliances, as it did in the transition to capitalism, particularly after the civil wars and the spread of anti-Jacobinism. The new definition of 'common weal' shifted the solidarities and allegiances of the rulers, from the commoners to capital owners. Moral duties regarding the redistribution of wealth were increasingly redesigned as charity and hitherto legitimate claims to price- fixing became attacks on property. All of this occurred at a time when the industrial revolution was unfolding, and laboring people's demands increasingly shifted from market regulation (exchange of goods and money) to the rise of wages (labor) and the end of Speenhamland (Thompson, 1991). Furthermore, Thompson's particular approach to class sets the moral economic approach apart from the embeddedness thesis. Polanyi is very sensitive to the class conflict underlying the epochal change he describes in The Great Transformation. For him, the role of the state as a coercing force plays a central role (Lie, 1991; Block, 2003; Bolton and Laaser, 2013). However, as Burawoy (2003) has observed, Polanyi operates with an old-fashioned class concept that assumes a working-class community is formed only in the light of external threats and has no independent consciousness. The latter describes how commodification led to the destruction of social institutions, but is unable to explain what led to the formation of class interests and mobilization in such a context of disorganization. Conversely, E.P. Thompson gives preeminence to people's agency. He valorizes the ongoing ethical evaluations of people during different periods of change, and shows the importance of working-class traditions for class formation: their cultural, political and economic resources. Thompson shows that the working-class mobilization that crystallized in the context of industrialization 'was forged not from anomie and desperation but from the 
organizational legacies of proto-industrialization of the North [.. .] The English working class could not be regarded as a blank slate, defenseless against market forces. It was already embedded in community, which gave it the weapons to defend itself and advance active society in its own name' (Burawoy, 2003: 222).

\section{Moral economy and hegemony}

Since the seminal works of Thompson and Scott, moral economists attentive to capital and class have been drawn to mobilizations that defy the established order and appeal to different moral values. A salient example is the work of Edelman, who has focused on how transnational networks of peasant movements mobilize against supranational institutions (2005). In particular, he looks at how projects of 'food sovereignty' are linked to moral claims regarding the right of those working the land to a fair and secure livelihood. However, in confining the analysis to the claims of mobilized peasants, Edelman paints a partial picture of the moral economic field they are inscribed in, disregarding other (conflicting) values and practices that might help us understand the limits around them.

Hence the question: since capital accumulation is metabolized through complex and contradictory fields of norms, meanings and practices, should we restrict the notion of moral economy only to actors seeking to alter it? Edelman's warning against emptying the concept of 'class content' (2012: 63) remains paramount, but the approach to class needs to be broader, including dynamics that do not necessarily correspond with political subject formation or organized conflict. Circumscribing the concept of moral economy to actors defending class struggle or leftist causes might prevent us from analyzing elements that explain, for instance, why people do not mobilize. Or why they do so, but according to reasons that are far removed from promoting social justice or the interests of 
minorities. As Hann (2010) has remarked, moral economy is not only about taking into account the values and norms that might lead to political action against the dominant powers or ideology but also those that might underpin positive visions of private property, the institutions of the market or racism, and that might be invoked to legitimate actions too. As he succinctly puts it: 'if moral economy is primarily a nexus of beliefs, practices and emotions among the folk, rather than an analytic concept designed to register only those beliefs, practices and emotions which conduce to action which the observer considers to be progressive, then we must conclude that even the reactionary right is entitled to its moral economy' (Hann, 2010: 195). In other words, while Edelman seems to equate the notion of moral economy with consciously organized class conflict (between rulers and ruled), Hann hints at a conceptualization that understands class dispositions and practices more broadly. In his text, Hann suggests that not even Thompson himself could get out of the normative approach characteristic in moral economists, particularly as he had trouble dealing with the fact that English workers were imbued with nationalist sentiments. Yet we think that Thompson's work offers an example of how differ- ences in Edelman's and Hann's visions of class can be bridged. His opera magna on the historical formation of the English working class is precisely a demonstration of the many contentious moral views (many of which did not coincide with his own) and lines of fracture traversing the social worlds of the different people that would eventually emerge as a political subject (1991 [1963]).

The debate around class also points to a terrain for the most part avoided, which has to do with the reproduction of power. There is a crossroads at which the concept of moral economy and that of hegemony inevitably meet, though recent scholarship on moral economy has not explored how. In recent years hegemony has 
become like the elephant in the room: while moral economists pay close atten- tion to some of the situated micro-mechanisms that reproduce (or alter) power structures at large, they generally avoid engaging with hegemony theories. This is a striking gap since both Thompson (1971) and Scott $(1985,1990)$ deal with the concept, mainly to disagree with the idea that hegemony entails uncontested acceptance by the poor of their domination.

In that sense, Dimitrios Gkintidis's refreshing look at the moral economy of European integration with regard to Greece and its articulation with the notion of hegemony is a very welcome exception. His study shows how differently positioned actors in the institutional structure of EU aid persistently frame the latter in terms of gifts and obligations, at the expense of other interpretations that could highlight structural inequalities. By recognizing the European Union as an abstract origin- ator of past solidarity gestures towards Greeks, technocrats justify today's austerity measures as 'reciprocal obligations'. From Gkintidis' point of view, this top-down moralization of relations between states and peoples legitimizes growing class inequalities and the reproduction of capitalist logics and practices. His elaboration brings together Fassin's ideas about the current moralization of politics and a Gramscian conception of hegemony as the cultural domination, by particular elites, of social formations. He concludes that hegemonic processes are sustained as long as the dominated adopt the explanatory frameworks of the dominant (in this case the solidary character of the EU). An important question to be answered is why and how this happens. Is it through the manipulation of cultural values and mores that elites can exert domination on the rest of society, justifying inequality as a natural and inevitable state of affairs? Gkintidis seems to respond affirmatively: by drawing a sharp line between structural and moral understand- ings, his conceptual apparatus assumes the existence 
of a realm or set of material structures that need to be distinguished from (and somewhat stripped of) their moral superstructure, so to speak.

According to this view, the moral seems to operate as an ideological shroud that legitimizes unequal outcomes. This stems partly from the fact that Gkintidis' empirical work looks specifically at the upper echelons of a supranational state institution. Building on this, it would be illuminating to complement this analysis with ethnographies of how non-elites - i.e. social majorities currently experiencing EU-led austerity cuts - relate to the same meanings and values. For instance, an analysis along the lines of Raymond Williams (1980) could suggest that such meanings and values are not only abstract but also organized and lived; that hegemony can be understood at the level of ideological manipulation or inter- est misrecognition but also as cultural domination that takes shape in everyday practices and expectations, thus constituting a particular sense of reality for most people. After all, as Williams remarked, if institutions simply conveyed the mean- ings and valuations of the elites, or of a section of the elites, and imposed them on the rest of society, then the dominant culture would be very easy to overthrow (1980: 38). Such an argument underscores the fact that the economic and the moral are deeply intertwined in other words, both are, in fact, structural.

Furthermore, the moral economic approach highlights the oftencontradictory values that guide and sustain livelihood practices, thus preserving anthropologists against the temptation to pigeonhole their interlocutors in predefined ideological frameworks. As Thompson suggested, while moral economy "cannot be described as "political" in any advanced sense, nevertheless it cannot be described as unpolitical either, since it suppose[s] definite and passionately held notions of the common weal' (1971: 79). This implies 
accounting for alternative meanings and values that are more or less accommodated within the dominant culture; practices and views that might legitimize dominant ones without fully endorsing them. In fact, class accommodation and hegemony might occur because of the constrained ways inequalities are embedded in mundane processes of reproduction and moral dependences that often do not leave much space for maneuver. These might as well be consciously recognized as such (see Kofti, this issue) without necessarily indicating a path to change.

\section{Conclusion}

Engaging with moral economy is not meant to revive a theoretical debate simply for the sake of theory. This paper seeks to both underline anthropology's capacity for holistic analysis and radical critique, and to respond to the intellectual urgency of the current historical moment. Our aim is therefore twofold. First, in the face of a bourgeoning anthropology of morals, we want to bring political economy to the center of anthropological analysis. In our understanding, moral economy is not political economy's 'other': it is not its historical antecedent in evolutionary terms; nor is it simply another scale of analysis. Moral economy is precisely the anthropological way to study the political economy. It deals since its inception with the practices, meanings and institutions that regulate social formations in a world increasingly dominated by the principles of capital accumulation. It is not therefore a synonym of the - often positively charged 'solidarity economies' functioning outside the market, or in its interstices (informal economy). Neither can it be deployed to simply account for micro-economic practices, such as networks of reciprocity and obligation that often cushion exploitation and crisis effects, without linking them to power relations at large. Moral economy, above all, is about understanding the inner 
workings of capitalism and the qualities of social reproduction at particular historical times and spaces. It is an approach that advocates an anthropological understanding of class (Wolf, 1982; Kalb, 1998; Narotzky and Smith, 2006; Carrier and Kalb, 2015), bringing under the same analytical frame- work different regimes of value and pointing to the complex ways they are entangled.

Second, we contend that this theoretical exercise is a timely anthropological task. Moral economy seems particularly suited to interpret moments of historical rupture, where tensions between analytical dimensions such as between the moral frameworks and the logics of accumulation are exacerbated. In this issue, we are putting together in essays and in dialogue fresh anthropological accounts of crisis-ridden Europe. All papers deploy the concept of moral economy in order to make sense of and explain current processes of structural dispossession, such as the flexibilization of labor, the institutional architecture of the European Union and migration or transitions between political-economic regimes. Albeit in quite different ways, the authors seek to understand the everydaygrounded logics of macro-economic (and political) processes by bringing together structural proper- ties and peoples' moral dispositions. After all, moral economy is all about tracing the multiscalar logics of power (Wolf, 1990), and power always involves struggle. Only by reading these two realms together can we understand current social mobilizations and silences, hegemony and counter-hegemony, continuity and change, or the mere conditions of possibility for them.

\section{Acknowledgements}

We would like to thank all the people that, one way or another, supported and co-produced this special issue: the participants and discussants of the ASA 2014 panel and, particularly, our contributors 
Dimitrios Gkintidis, Dimitra Kofti and Valerio Simoni for a fascinating debate, their hard work and patience; the editors of Anthropological Theory, and two anonymous reviewers for their fruitful feedback; and Susana Narotzky for her intellectual inspiration and useful advice.

\section{Funding}

The organization of the ASA panel, and the research and writing of this article, have been fully funded by the European Research Council Advanced Grant 'Grassroots Economics: Meaning, Project and Practice in the Pursuit of Livelihood' [GRECO], IDEAS-ERC FP7, Project Number: 323743.

\section{Note}

1. This paper is a theorization on moral economy that re-assesses the existing literature while providing an introductory framework to the new special issue of Anthropological Theory, devoted to this question. The journal's new number features a series of articles that were originally presented at a panel of the ASA (Association of Social Anthropologists of the UK and Commonwealth) decennial conference in Edinburgh, June 2014. The chosen title, 'Moral Economy in Crisis', reflects two aspects of the discussion at stake. First, it highlights the analyses of Gkintidis, Kofti and Simoni (this issue) that stem from research among social groups which have been impacted by the ongoing European crisis, in one way or another. Second, and most importantly, the title of this special issue conveys a collective desire to problematize the notion of moral economy and put its conceptual relevance to test.

\section{References}

Appadurai A (1988) The Social Life of Things: Commodities in Cultural 
Perspective. Cambridge: Cambridge University Press.

Blim M (1990) Made in Italy: Small-Scale Industrialization and Its Consequences. New York: Praeger.

Block F (2001) Introduction. In: Polanyi K (ed.) The Great Transformation. Boston, MA: Beacon Press, pp. xviii-xxxviii.

Block F (2003) Karl Polanyi and the writing of The Great Transformation. Theory and Society 32(3): 275-306.

Bolton SC and Laaser K (2013) Work, employment and society through the lens of moral economy. Work, Employment \& Society 27(3): 508-525.

Booth WJ (1994) On the idea of the moral economy. The American Political Science Review 88(3): 653-667.

Burawoy M (2003) For a sociological Marxism: The complementary convergence of Antonio Gramsci and Karl Polanyi. Politics \& Society 31(2): 193261.

C, alıs, kan K and Callon M (2009) Economization, part 1: Shifting attention from the econ- omy towards processes of economization. Economy and Society 38(3): 369-398.

Callon M (2007) What does it mean to say that economics is performative? In: MacKenzie D, Muniesa F and Siu L (eds) Do Economists Make Markets? On the Performativity of Economics Princeton, NJ: Princeton University Press, pp. 311-357.

Carrier JG and Kalb D (eds) (2015) Anthropologies of Class: Power, Practice, and Inequality. Cambridge: Cambridge University Press.

Daston L (1995) The moral economy of science. Osiris 10: 3-24.

Edelman M (2005) Bringing the moral economy back in ... to the study of 21stcentury transnational peasant movements. American Anthropologist 107(3): 331345.

Edelman M (2012) E.P. Thompson and moral economies. In: Fassin D (ed.) A Companion to Moral Anthropology. New York: John Wiley \& Sons, pp. 49-66.

Fassin D (2009) Les e' conomies morales revisitées. Annales. Histoire, Sciences Sociales 6: 1237-1266.

Fassin D (2012) A Companion to Moral Anthropology. Hoboken, NJ: WileyBlackwell.

Fox-Genovese E (1973) The many faces of moral economy: A contribution to a debate. Past and Present 58(1): 161-168.

Ghezzi S (2003) Local discourse and global competition: Production experiences in family workshops of the Brianza. International Journal of Urban and Regional 
Research 27(4): 781-792.

Götz N (2015) 'Moral economy': Its conceptual history and analytical prospects. Journal of Global Ethics 11(2): 147-162.

Graeber D (2001) Toward an Anthropological Theory of Value: The False Coin of Our Own Dreams. New York: Palgrave.

Granovetter M (1985) Economic action and social structure: The problem of embeddedness. American Journal of Sociology 91(3): 481-510.

Gregory C (1982) Gifts and Commodities. Cambridge: Cambridge University Press. Gregory C (1997) Savage Money: The Anthropology and Politics of Commodity Exchange. Cambridge: Cambridge University Press.

Gudeman S (2008) Economy's Tension: The Dialectics of Community and Market. New York: Berghahn.

Guyer J (2004) Marginal Gains: Monetary Transactions in Atlantic Africa. Chicago, IL: University of Chicago Press.

Hann C (2010) Moral economy. In: Hart K, Laville JL and Cattani AD (eds) The Human Economy: A Citizen's Guide. Cambridge: Polity Press, pp. 187-198.

Hart C (2000) The Memory Bank: Money in an Unequal World. London: Profile. Hart K and Hann C (2011) Introduction: Learning from Polanyi. In: Hann C and Hart K (eds) Market and Society: The Great Transformation Today. Cambridge: Cambridge University Press, pp. 1-16.

Kalb D (1998) Expanding Class: Power and Everyday Politics in Industrial Communities, The Netherlands 1850-1950. Durham, NC: Duke University Press.

Karandinos G, Hart LK, Castrillo FM and Bourgois P (2014) The moral economy of vio- lence in the US inner city. Current Anthropology 55(1): 1-22.

Krippner GR (2001) The elusive market: Embeddedness and the paradigm of economic sociology. Theory and Society 30(6): 775-810.

Krippner G, Granovetter M, Block F, Biggart N, Beamish T, Hsing Y, Hart G, Arrighi G, Mendell M, Hall J, Burawoy M, Vogel S and O'Riain S (2004) Polanyi Symposium: A conversation on embeddedness. Socio-Economic Review 2: 109135.

Langegger S (2015) After the ban: The moral economy of property. Antipode 48(3): 22. DOI: 10.1111/anti.12204. Abstract available at: http://onlinelibrary.wiley.com/doi/10.1111/ anti.12204/abstract.

Lie J (1991) Embedding Polanyi's market society. Sociological Perspectives 34(2): 219-235.

Mauss M (2003 [1923-4]) Essai sur le don: Forme et raison de l'êchange dans 
les societies archai" ques. In: Mauss M (ed.) Sociologie et anthropologie. Paris: Presses Universitaires de France.

Moore B (1966) Social Origins of Dictatorship and Democracy: Lord and Peasant in the Making of the Modern World. Harmondsworth: Penguin Books. Munn N (1992) The Fame of Gawa: A Symbolic Study of Value Transformation in a Massim (Papua New Guinea) Society. Durham, NC: Duke University Press.

Narotzky S (2015) The payoff of love and the traffic of favors: Reciprocity, social capital, and the blurring of value realms in flexible capitalism. In: Kjaerulff $\mathrm{J}$ (ed.) Flexible Capitalism: Exchange and Ambiguity at Work. Oxford: Berghahn, pp. $268-310$

Narotzky S and Besnier N (2014) Crisis, value, and hope: Rethinking the economy: An introduction to Supplement 9. Current Anthropology 55(S9): S4S16.

Narotzky S and Smith G (2006) Immediate Struggles: People, Power, and Place in Rural Spain. Berkeley: University of California Press.

Olivier de Sardan JP (1999) A moral economy of corruption in Africa? The Journal of Modern African Studies 37(1): 25-52.

Orlando G (2010) New Moral Economies in Western Sicily: Fair-trade and Organic Agriculture between Change and Constraint. PhD thesis, Goldsmiths, University of London, UK.

Orlove BS (1997) Meat and strength: The moral economy of a Chilean food riot. Cultural Anthropology 12(2): 234-268.

Palomera J (2014) Reciprocity, commodification, and poverty in the era of financialization. Current Anthropology 55(9): S105-S115.

Perelman M (2000) The Invention of Capitalism: Classical Political Economy and the Secret History of Primitive Accumulation. Durham, NC: Duke University Press.

Polanyi K (2001) The Great Transformation: The Political and Economic Origins of Our Time. Boston, MA: Beacon Press.

Popkin SL (1979) The Rational Peasant: The Political Economy of Rural Society in Vietnam. Berkeley: University of California Press.

Psarikidou K and Szerszynski B (2012) The moral economy of civic food networks in Manchester. International Journal of Sociology of Agriculture and Food 19(3): 309-327.

Robbins J (2007) Between reproduction and freedom: Morality, value, and radical cultural change. Ethnos 72(3): 293-314. 
Sabel C (1991) Moebius strip organizations and open labor markets: Some consequences of the reintegration of conception and execution in a volatile economy. In: Bourdieu P and Coleman J (eds) Social Theory for a Changing Society. Boulder, CO: Westview Press, pp. 23-54.

Sayer A (2000) Moral economy and political economy. Studies in Political Economy 61: 79-103.

Scott JC (1976) The Moral Economy of the Peasant: Rebellion and Subsistence in Southeast Asia. New Haven, CT: Yale University Press. Scott JC (1985) Weapons of the Weak: Everyday Forms of Peasant Resistance. New Haven, CT: Yale University Press.

Scott JC (1990) Domination and the Arts of Resistance. New Haven, CT: Yale University Press.

Scott JC (2005) Afterword to 'Moral Economies, State Spaces, and Categorical Violence'. American Anthropologist 107(3): 395-402.

Strathern M (1988) The Gender in the Gift: Problems with Women and Problems with Society in Melanesia. Berkeley: University of California Press. Thompson EP (1971) The moral economy of the English crowd in the eighteenth century. Past \& Present 22(50): 76-136.

Thompson EP (1991) The moral economy reviewed. In: Thompson EP (ed.) Customs in Common: Studies in Traditional Popular Culture. London: Penguin Books, pp. 259-351. Thompson EP (1991 [1963]) The Making of the English Working Class. London: Penguin Books.

Tripp C (2006) Islam and the Moral Economy: The Challenge of Capitalism. Cambridge: Cambridge University Press.

Wegren SK (2005) The Moral Economy Reconsidered: Russia's Search for Agrarian Capitalism. New York: Palgrave Macmillan.

Weiner A (1992) Inalienable Possessions: The Paradox of Keeping-WhileGiving. Berkeley: University of California Press.

Williams R (1980) Base and superstructure in Marxist cultural theory. In:

Williams R, Culture and Materialism. London: Verso, 31-49.

Wolf E (1969) Peasant Wars of the Twentieth Century. New York: Harper and Row.

Wolf E (1982) Europe and the People without History. Berkeley: University of California Press.

Wolf E (1990) Distinguished Lecture: Facing power: Old insights, new questions. American Anthropologist 92(3): 586-596.

Zelizer VA (1988) Beyond the polemics on the market: Establishing a theoretical 
and empirical agenda. Sociological Forum 3(4): 614-634.

Zigon J (2007) Moral breakdown and the ethical demand: A theoretical framework for an anthropology of moralities. Anthropological Theory 7(2): 131150.

Zigon J (2014) An ethics of dwelling and a politics of world-building: A critical response to ordinary ethics. Journal of the Royal Anthropological Institute (N.S.) 20: 746-764.

Jaime Palomera is an anthropologist trained in the critique of political economy. $\mathrm{He}$ has conducted ethnographic research in the urban peripheries of Barcelona and Tarragona since 2006, analyzing a variety of contemporary topics: financialization, class and culture, home ownership, urban inequality, migration and political mobi- lization. He is currently a post-doctoral researcher in the ERC Grassroots Economics Project.

Theodora Vetta is an ERC post-doctoral researcher at the Grassroots Economics Project, University of Barcelona. Her doctoral work (École des Hautes Études en Sciences Sociales) unpacks the NGO "associational revolution" in Serbia by looking at the global political economy of Aid, state and labor restructuring, and processes of subjectification that come along "civil society" projects. Her current research focuses on private/public debt, unionism, class fragmentation, and priva- tization of energy production in Greece. 